\title{
Introduction to the special issue on "ICTs and Society: PhD Students' Transdisciplinary Research Projects"
}

\section{Christian Fuchs}

ICT\&S Center: Advanced Studies and Research in Information and Communication Technologies \& Society, Sigmund Haffner Gasse 18, 5020 Salzburg, Austria; christian.fuchs@sbg.ac.at

th he study of the interrelationship of ICTs, mobile technologies, the Internet, etc on the one hand and society on the other hand has during the past few years been labeled with categories like Internet Research, ICTs and Society, Social Informatics, Informatics and Society, New Media Research, Information Society Theory, Information Society Research/Studies, Internet Studies, Web Research, etc. In recent times, the term ICTs and society has become one of the most important notions for describing this new transdisciplinary field (Fuchs, 2008; Hofkirchner, Fuchs, Raffl, Schafranek, Sandoval, and Bichler, 2007). society. Two interconnected aspects of ICT\&S research are:

- The social shaping/social design of ICTs.

- The impacts of ICT usage on society.

The task of this field is the analysis of these relationships and the contribution to the design of society and ICTs so that a participatory knowledge society can emerge (Fuchs, 2008). ICT\&S research deals with opportunities and risks of the knowledge society and the shaping of technology and social systems.

The research field of ICT\&S deals with the interplay of new information and communication technologies (ICTs) and

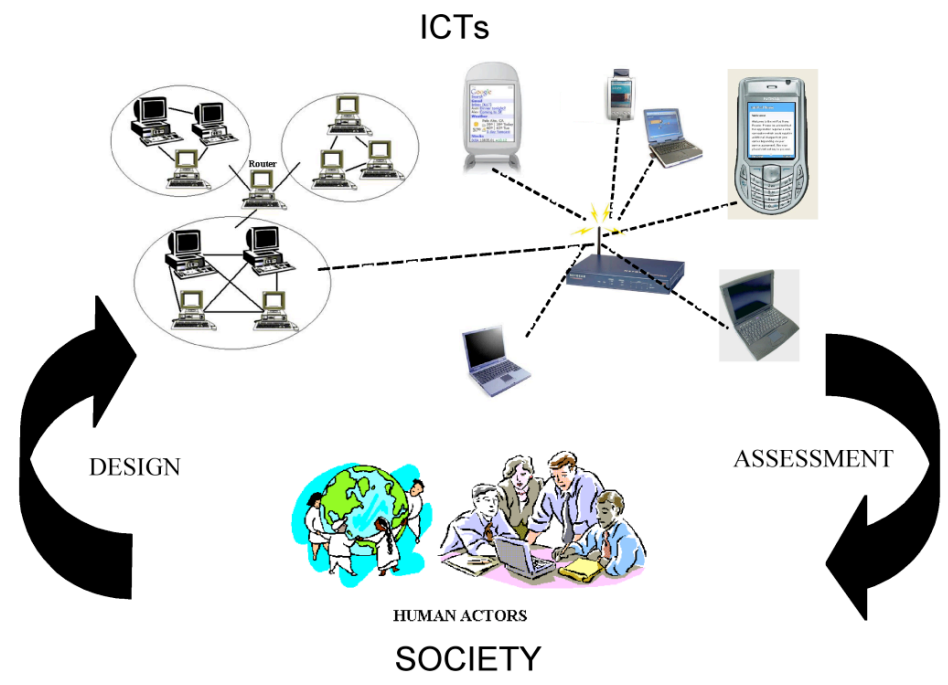

Figure 1: ICT\&S Research 
ICTs and society-research is a double process, consisting of:

1. A process, in which human actors design ICTs and in which it is analyzed how society shapes ICTs, and

2. A process, in which it is assessed how the usage of ICTs transforms society (figure 1). That ICTs are shown at another level than society here does not mean that they exist outside of it. Rather ICTs are an immanent part of society.

For mapping the research landscape of ICTs and society-research, a general concept of society that identifies subdomains is needed (Fuchs, 2008).

Models of society that see society as being composed of independent subsystems, such as Luhmann's (1984) theory of functional differentiation, face the problem of explaining phenomena that are characteristic for the global network society. So they e.g. cannot analyze and criticize that today economic logic influences and colonizes large parts of society. In contrast to reductionistic and relativistic social theories, dialectical social theories (such as the theoretical frameworks provided by Pierre Bourdieu, Roy Bhaskar, Margaret Archer, or Anthony Giddens that are based on a dialectic of structures and agency/human actors) have proved successful in conceiving society as being composed of relative autonomous subsystems that all have their own specificity, but nonetheless depend on each other and influence each other. The subsystems are conceived as distinct and at the same time mutually interdependent, which is the fundamental logical figure of dialectical thinking.

Society can be conceived as consisting of interconnected subsystems that are not independent and based on one specific function they fulfill, but are open, communicatively interconnected, and networked. As subsystems of a model of society one can conceive the ecological system, the technological system, the economic system, the political system, and the cultural system (Fuchs, 2008; cf. figure 2).

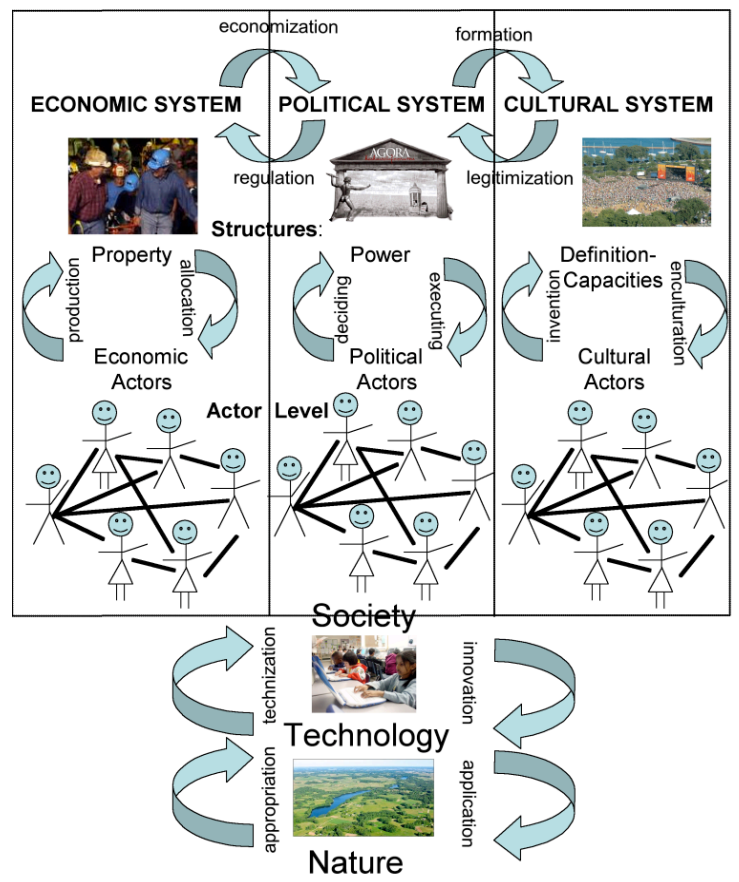

Figure 2: Society as dynamic, dialectical system (Fuchs, 2008) 
Why exactly these systems? In order to survive, humans in society have to appropriate and change nature (ecology) with the help of technologies so that they can produce resources that they distribute and consume (economy), which enables them to make collective decisions (polity), form values, and acquire skills (culture). The core of this model consists of three systems (economy, polity, culture). This distinction can also be found in other contemporary sociological theories: Giddens (1984, p. 2834) distinguishes between economic institutions, political institutions, and symbolic orders/modes of discourse as the three types of institutions in society. Bourdieu (1986) speaks of economic, political, and cultural capital as the three types of structures in society. Jürgen Habermas (1981) differs between the lifeworld, the economic system, and the political system. Human actors and social structures that are produced by the actors and condition the actors' practices shape each of these systems. Each subsystem is defined and permanently recreated by a reflexive loop that productively interconnects human actors and their practices with social structures. An overview of the qualities of structuring and structured structures in society is given in table 1 .

\begin{tabular}{lll}
\hline Type of structure & Structure & Definition \\
\hline Ecological structures & $\begin{array}{l}\text { (Natural) } \\
\text { resources }\end{array}$ & $\begin{array}{l}\text { Physical matter that is extracted in labor processes } \\
\text { from nature and that is changed by human activities. }\end{array}$ \\
\hline Technological structures & Tools & $\begin{array}{l}\text { Artifacts, means, methods, skills of action that are used } \\
\text { by humans in order to try to achieve defined goals. }\end{array}$ \\
\hline Economic structures & Property & $\begin{array}{l}\text { Goods and resources that are produced, distributed, } \\
\text { and used by humans for satisfying defined needs. }\end{array}$ \\
Political structures & Power & $\begin{array}{l}\text { The capacity and means for influencing collective } \\
\text { decisions according to one's own will. }\end{array}$ \\
Cultural structures & $\begin{array}{l}\text { Definition- } \\
\text { capacities }\end{array}$ & $\begin{array}{l}\text { The capacity to define and acquire values, skills, and } \\
\text { practices that shall give meaning to life and help re- } \\
\text { create human minds and bodies. }\end{array}$ \\
\hline
\end{tabular}

Table 1: An overview of structures in society (Fuchs, 2008)

The economic system can only produce goods that satisfy human needs by human labor power that makes use of productive and communication technologies in order to establish social relations and change the state of natural resources. The latter are transformed into economic goods by the application of technologies to nature and society in labor processes. Hence the economy is based on a dialectic of natural resources and labor that is mediated by technology. We hence can argue that socially transformed nature and technology are aspects of the economic system.

The following table visualizes the landscape of research on ICTs and society and shows how the papers in this special issue fit into this landscape. 


\begin{tabular}{|c|c|c|c|c|}
\hline $\begin{array}{l}\text { Ecological } \\
\text { System }\end{array}$ & $\begin{array}{l}\text { Technological } \\
\text { System }\end{array}$ & $\begin{array}{l}\text { Economic } \\
\text { System }\end{array}$ & $\begin{array}{l}\text { Political } \\
\text { System }\end{array}$ & $\begin{array}{l}\text { Cultural } \\
\text { System }\end{array}$ \\
\hline \multirow[t]{2}{*}{$\begin{array}{l}\text { Research } \\
\text { examples: } \\
\text { ecological } \\
\text { balance of ICTs, } \\
\text { material flow } \\
\text { analysis of ICT } \\
\text { sector, ecological } \\
\text { sustainability of } \\
\text { ICTs, analysis of } \\
\text { e-waste } \\
\text { production and } \\
\text { flows }\end{array}$} & $\begin{array}{l}\text { Research } \\
\text { examples: } \\
\text { Human Computer } \\
\text { Interaction, } \\
\text { Usability Research, } \\
\text { User Interface } \\
\text { Design }\end{array}$ & $\begin{array}{l}\text { Research } \\
\text { examples: } \\
\text { digital economy, } \\
\text { knowledge } \\
\text { management, } \\
\text { virtual } \\
\text { corporations, } \\
\text { Web } 2.0 \\
\text { economy, e- } \\
\text { commerce, new } \\
\text { economy } \\
\text { analyses, } \\
\text { Internet } \\
\text { business } \\
\text { strategies, } \\
\text { knowledge } \\
\text { labour, } \\
\text { knowledge } \\
\text { industry }\end{array}$ & $\begin{array}{l}\text { Research } \\
\text { examples: } \\
\text { digital divide, } \\
\text { online politics, } \\
\text { digital } \\
\text { democracy, } \\
\text { information } \\
\text { warfare, cyber } \\
\text { protest, } \\
\text { electronic } \\
\text { surveillance, } \\
\text { electronic } \\
\text { participation }\end{array}$ & $\begin{array}{l}\text { Research } \\
\text { examples: } \\
\text { virtual } \\
\text { communities, } \\
\text { cyber science, } \\
\text { cyber love, } \\
\text { cybersex, cyber } \\
\text { pornography, } \\
\text { eHealth, social } \\
\text { networking } \\
\text { platforms, online } \\
\text { friendships, cyber } \\
\text { hate, computer } \\
\text { games, } \\
\text { eLearning, online } \\
\text { journalism }\end{array}$ \\
\hline & & & $\begin{array}{l}\text { Papers in this } \\
\text { special issue: } \\
\text { Bichler, Mattoni, } \\
\text { Neto }\end{array}$ & $\begin{array}{l}\text { Papers in this } \\
\text { special issue: } \\
\text { Abdul-Mageed, } \\
\text { Kemp, Pepe }\end{array}$ \\
\hline
\end{tabular}

Table 2: The landscape of research on ICTs and society

Although some scholars claim that the field of ICTs and society is an interdiscipline (Duff, 2000 , p. 180), a new discipline (Vehovar, 2006), or an indiscipline (Shrum, 2005), a widely held position is that it is a transdisciplinary field (e.g. Hunsinger, 2005; Lamb \& Sawyer, 2005; Sawyer \& Tyworth, 2006)

Manfred Max-Neef (2005) defines transdisciplinarity as analyses that include four levels: an empirical one (What exists?), a purposive or pragmatic one (What are we capable of doing?), a normative one (What do we want to do?), and a value level (What should we do? How should we do what we want to do?). According to this understanding, values, ethics, and philosophy are central aspects of transdisciplinarity.

"Transdisciplinarity, more than a new discipline or super-discipline, is, actually, a different manner of seeing the world, more systemic and more holistic." (MaxNeef, 2005, p. 15)
Basarab Nicolescu (2000) speaks of transdisciplinarity in the context of the analysis of different levels of reality that are united in transdisciplinary research. The need for transdisciplinary research arises in contemporary society because of the complexity of its problems that affect many interconnected realms of existence (Klein, 2004; Lawrence \& Després, 2004). Social science and computer science are the two different levels that are united in ICTs and society-research.

Lawrence and Després (2004) stress that transdisciplinarity "deals with research problems and organizations that are defined from complex and heterogeneous domains" (Lawrence \& Després, 2004, p. 399). The research domain of this special issue of tripleC is the interconnection of computer usage and societal development. Nicolescu $(1997 ; 2000)$ identifies three central aspects of transdisciplinary: the concept of levels of reality, the logic of the included middle ("there exists a third term $T$ which is at the same time $A$ and non-A", [Nicolescu, 2000]), and 
complexity. Transdisciplinarity "concerns the dynamics engendered by the action of several levels of Reality at once. The discovery of these dynamics necessarily passes through disciplinary knowledge. While not a new discipline or a new superdiscipline, transdisciplinarity is nourished by disciplinary research; in turn, disciplinary research is clarified by transdisciplinary knowledge in a new, fertile way. In this sense, disciplinary and transdisciplinary research are not antagonistic but complementary" (Nicolescu, 1997). For connecting computer science and the social sciences, a unity that maintains the disciplinary diversity can be constructed by an included third, i.e. social philosophy. Based on such a general mediation, concrete studies of ICTs and society are possible that are grounded in theoretical foundations. The papers presented in this special issue focus on the concrete level, whereas other works deal with the meta-theoretical foundations (e.g. Duff, 2000; Dyer-Witheford, 1999; Galloway, 2007; Graham, 2005; Hassan, and Thomas, 2006; Lovink, 2007; Manovich, 2001; Rossiter, 2006; Webster, 2002; Webster, and Blom, 2004; Fuchs, 2008; Hofkirchner, 2007; Hofkirchner, Fuchs, Raffl, Schafranek, Sandoval, and Bichler, 2007; Slevin, 2000).

On June 20-21, 2008, a doctoral students' conference and a network meeting of senior researchers in the field of ICTs and society took place at the University of Salzburg. Christian Fuchs and Wolfgang Hofkirchner, heads of the eTheory Research Group of the ICT\&S Center, organized the event. 42 doctoral students from 17 different countries participated in the students' conference. 14 doctoral projects were presented and discussed (see http://www.icts-andsociety.net/phd/). These students are all writing dissertations on topics in the field of information and communication technologies \& society. The topics covered included ICTs and development, digital divide, networked and mobile sociality, characteristics of the blogosphere, online identity, language and Internet, cyber protest, ICTs and civil society, online journalism, interdisciplinary knowledge production, mobile Internet, participatory geographic information systems, and participatory online media culture.
The students prior to the conference submitted full papers that were reviewed by senior scholars and other doctoral students, who then acted as respondents at the event. As senior respondents, well-respected international ICT\&S experts were involved: Gunilla Bradley (Royal Institute of Technology, Stockholm, Sweden), Niels Ole Finneman (Center for Internet Studies, Arhus, Denmark), László Karvalics (University of Szeged, Hungary), Leah Lievrouw (University of California, Los Angeles, USA), Brian D. Loader (Social Informatics Research Unit, University of York, UK), Alice Robbin (Rob Kling Center for Social Informatics, Bloomington, USA).

The student respondents were: Daniela de Carvalho Matielo (Open University of Catalonia, Barcelona, Spain), Stine Lomborg (University of Aarhus, Denmark), Alice Mattoni (European University Institute, Italy), Celina Raffl (University of Salzburg),

As ICT\&S is still a new research field that is on its way of becoming ever more important and institutionalized, networking ICT\&S students on an international level is an essential task. Thus far students in this field still have to study mainly within traditional disciplines. There are hardly any doctoral programs existing in the fields of ICTs and society, New Media Research, and Social Informatics. Therefore international networking is important.

6 papers of $\mathrm{PhD}$ students that were presented at the Salzburg conference, are published in this special issue of tripleC.

Muhammad M. Abdul-Mageed covers the topic "Online news sites and journalism 2.0: Reader comments on Al Jazeera Arabic". The goal of the paper is to assess the degree of interactivity of the Arabic version of the Al Jazeera website. Comments and stories are analyzed by content analysis for a period of six weeks. The author found that the top story, which has a featured position on the site, received most of the comments $(16.44 \%)$, that there was a clustering of stories and 
comments around three topical realms: politics (34\% of stories, $32 \%$ of comments), military and political violence $(30 \%$ of stories and $31 \%$ of comments), foreign relations ( $24 \%$ of stories and $27 \%$ of comments), and that the majority of stories and comments was focusing on topics that concern the Arab world (stories: $62 \%$, comments: $73 \%$ ). The author concludes that the political situation in the Middle East, the global interest in the Arab world after $9 / 11$, and pressure exerted by US politics and military interventions have caused active interest in politics, which results in a high interest in political stories and in commenting on them in the case of $\mathrm{Al}$ Jazeera.

Robert M. Bichler's paper focuses on "The dawn of the information age in least developed countries (LDCs): Lessons learned from four case studies". The aim is to discuss political aspects and policy issues of ICT usage in least developed countries. The author takes a critical position and argues that in the current implementation forms, ICT usage results in economic, political, cultural, technological, and ecological colonization of developing countries by Western corporations, values, and standards. The author coins a new term in this context eColonization. The paper can be understood as a meta-reflection of the political issues that underlie the case studies that the author has undertaken in Yemen, Guatemala, Malawi, and Lao PDR. Suggestions for the foundation of an alternative policy framework that shall advance sustainability are made.

Randall B. Kemp's topic is: "Public participatory GIS in community-based disaster risk reduction". The project of the author is a case study of how to best use GIS technologies in disaster-prone small local communities in developing countries for disaster risk reduction (DRR). The method employed is one of participatory action research, in which the local stakeholders should benefit from research, be actively involved, and use the results in their local community for implementing and carrying out disaster reduction by themselves. This is considered as a process of empowerment.
The author outlines the overall research framework and its theoretical foundations (information, information science).

Alice Mattoni's paper deals with "ICTs in national and transnational mobilizations". The aim is to analyze the communication practices of the Euro Mayday Parade (EMP), an Italian and transnational protest movement against precarious labour. Methodologically, the author conducted 23 semi-structured interviews and employed content analysis of relevant documents. At the national level, the author found that for organizational tasks, both face-to-face assemblies and media like the Precog mailing list and Indymedia Italy were important. Identity formation processes by ICTs were limited because many precarious workers could not be reached by ICTs. Here more traditional media like leaflets and social media were employed. At the transnational level, ICTs were important means of organization: Besides transnational F2F meetings e.g. the Euro Mayday mailing list was used. Concerning identity formation, the situation was different at the transnational level than on the national level: Face to face meetings could not be organized frequently, therefore mechanisms and tools like a joint website, a virtual parade with avatars, virtual floats, the exchange of local and national activism reports, sharing of videos, images, and narratives, and the EMP live radio broadcasting helped to construct feelings of belonging to a common movement.

Pedro Neto's contribution "Internet-driven changes in environmental NGO action" deals with how ICTs are used by four environmental NGOs in Portugal. Qualitative methods such as interviewing, observation, and qualitative content analysis are used. The author found that in all four NGOs, ICTs have become central means of organization (internal communication, communication with the public, external communication, and forming of networks). He points out that the problems environmental NGOs are facing in Portugal are of political and cultural nature: There is no tradition of voluntary political action, the political system is rather centralized, which poses a disadvantage for civil society, 
Portuguese citizens more rely on traditional media than on the Internet for getting political information, and there is not much political activism.

Alberto Pepe's topic is: "Mining epistemic communities in 'little science' research". The author argues that interdisciplinary cooperation has become more important in academia. The paper analyzes interdisciplinary work at the Center for Embedded Networking Sensing (CENS). The author argues that interdisciplinary knowledge production is shaped by social, cultural, disciplinary, and financial context variables. $\mathrm{He}$ analyzes collaborative efforts with the help of the method of domain analysis. Publications were analyzed for co-authorship for a period of 10 years. One important result is that there is a fragmentation into 27 structural communities of co-authorship that have a highly connected inner structure and not many outer connections, and therefore represent "cliquish" structures.

The special issue of tripleC at hand shows that the study of the interrelationship of networked digital technologies and society is a lively research field, that transdisciplinarity needs to create and make use of international networks for advancing its own institutionalization, and that there is a generation of young scholars that is ready to transform the traditional disciplinary ways of how we are doing research.

\section{References}

Bourdieu, P. (1986). The (Three) Forms of Capital. In J. G. Richardson (Ed.), Handbook of Theory and Research in the Sociology of Education (pp. 241-258). New York: Greenwood Press.

Duff, A. S. (2000). Information Society Studies. New York: Routledge.

Dyer-Witheford, N. (1999). Cyber-Marx. Cycles and Circuits of Struggle in High Technology Capitalism. Urbana, IL: University of Illinois Press.

Fuchs, C. (2008). Internet and Society: Social Theory in the Information Age. New York: Routledge.

Galloway, A. R. (2007) The Exploit. A Theory of Networks. Minneapolis, MN: University of Minnesota Press.

Giddens, A. (1984). The Constitution of Society. Outline of the Theory of Structuration. Cambridge: Polity Press.

Graham, P. W. (2005). Hypercapitalism. New York: Peter Lang.

Habermas, J. (1981). Theorie des kommunikativen Handelns. (Vol. 2) Frankfurt/Main: Suhrkamp.

Hassan, R. \& Thomas, J. (2006) The New Media Theory Reader. New York: Open University Press.

Hofkirchner, W. (2007). A Critical Social Systems View of the Internet. Philosophy of the Social Sceinces, 37(4), 471-500.

Hofkirchner, W. \& Fuchs, C. \& Raffl, C. \& Schafranek, M. \& Sandoval, M. \& Bichler, R. (2007). ICTs and Society: The Salzburg Approach. Towards a Theory for, about, and by means of the Information Society (Research Paper No. 3 , ISSN 1990-8563). Salzburg: University of Salzburg, ICT\&S Center. Retrieved December 3, 2008, from http://icts.sbg.ac.at/media/pdf/pdf1490.pdf

Hunsinger, J. (2005). Toward a Transdisciplinary Internet Research. The Information Society, 21(4), 277-279.

Klein, J. T. (2004). Prospects for transdisciplinarity. Futures, 36(4), 515-526.

Lamb, R. \& Sawyer, St. (2005). On Extending Social Informatics from a Rich Legacy of Networks and Conceptual Resources. Information Technology \& People, 18(1), 9-20.

Lawrence, R. J. \& Després, C. (2004). Futures of transdisciplinarity. Futures, 36(4), 397-405.

Lovink, G. (2007). Zero Comments. Blogging and Critical Internet Culture. New York: Routledge.

Luhmann, N. (1984). Soziale Systeme. Frankfurt/Main: Suhrkamp.

Manovich, Lev (2001). The Language of New Media. Cambridge, MA: MIT Press.

Max-Neef, M. A. (2005). Foundations of transdisciplinarity. Futures, 53(1), 5-16.

Nicolescu, B. (1997). The Transdisciplinary Evolution of the University: Condition for Sustainable Development. Retrieved October 28, 2008, from International Center for Transdisciplinary Research Web site: http://nicol.club.fr/ciret/bulletin/b12/b12c8.htm

Nicolescu, B. (2000). Transdisciplinarity and Complexity: Levels of Reality as Source of Indeterminacy. Retrieved October 28, 2008, from International Center for Transdisciplinary Research Web site: http://nicol.club.fr/ciret/bulletin/b15/b15c4.htm 
Rossiter, N. (2006). Organized Networks. Rotterdam: NAi.

Sawyer, S. \& Tyworth, M. (2006). Social Informatics: Principles, Theory, and Practice. In J. Berleur \& M. I. Nurminen \& J. Impagliazzo (Eds.), Social Informatics: An Information Society for All? (pp. 49-62). New York: Springer.

Slevin, J. (2000). The Internet and Society. Cambridge: Polity.

Shrum, W. (2005). Internet Indiscipline: Two Approaches to Making a Field. The Information Society, 21(4), 273-275.

Vehovar, V. (2006). Social Informatics: An Emerging Discipline? In J. Berleur \& M. I. Nurminen \& J. Impagliazzo (Eds.), Social Informatics: An Information Society for All? (pp. 73-85). New York: Springer.

Webster, F. (2002). Theories of the Information Society. New York: Routledge.

Webster, F. \& Blom, Raimo, eds. (2004). The Information Society Reader. New York: Routledge. 